\title{
A record of deglaciation-related shifting of the proximal zone of a sandur - a case study from the Gwda sandur, NW Poland (MIS 2)
}

Mateusz Mleczak ${ }^{*}$ and Małgorzata Pisarska-Jamroży

\begin{abstract}
The study analyses a 7.5-m-thick sedimentary succession deposited in the largest sandur (the Gwda sandur, a glacial outwash plain) in NW Poland, during the late Weichselian (MIS 2). Although the study site is located in the distal zone of the sandur, its sedimentological features and palaeohydrological parameters reflect the presence of an energetic, powerful environment typical of the proximal zone. Three sedimentary units were recognized in the studied sedimentary succession: (1) lower unit - fine-grained sands with ripple cross-lamination and horizontal lamination; (2) middle unit - gravelly coarse-grained sands and sandy gravels with planar cross-stratification; and, (3) upper unit - sands and gravelly sands with trough cross-stratification. Although the age of deposition of the sandur is accepted to be convergent with that of end-moraines of the same phase, the sediments in the distal zone of the Gwda sandur correlate with an earlier glaciation phase/subphase. Our findings hint at a complex problem: large sandurs such as the Gwda sandur were probably deposited over a long time, and their successions might record the textural and structural features of the proximal subenvironment, even in their distal parts due to deglaciation-related shifting of the proximal zone of a sandur. This paper presents a new approach to analysing the depositional processes in large sandurs, shows a new light on glaciofluvial water supply dynamics of distal parts of sandurs, and may solve several fundamental problems related to the sandur deposition.
\end{abstract}

Keywords: Quaternary, Late Weichselian, Sandur, Deglaciation, Sedimentology, Floods

\section{Introduction}

Sandurs are outwash plains formed by meltwater flowing from the end of an ice sheet (Zieliński and Van Loon 2003). In sandurs, the style of sedimentation deposited by meltwaters depends on the flow competence, which in turn, is related to the distances from the ice sheet margin and the ablation rate. The proximal zone of the sandur, located close to the ice sheet, typically receives most of the deposited coarse-grained sediments (see Boothroyd and Ashley 1975; Boothroyd and Nummedal 1978; Zieliński 1993). This deposition is believed to

\footnotetext{
* Correspondence: mateusz.mleczak@amu.edu.pl

Institute of Geology, Adam Mickiewicz University, B. Krygowskiego 12, 61-680
} Poznań, Poland

\section{Springer Open}

(c) The Author(s). 2021 Open Access This article is licensed under a Creative Commons Attribution 4.0 International License, which permits use, sharing, adaptation, distribution and reproduction in any medium or format, as long as you give appropriate credit to the original author(s) and the source, provide a link to the Creative Commons licence, and indicate if changes were made. The images or other third party material in this article are included in the article's Creative Commons licence, unless indicated otherwise in a credit line to the material. If material is not included in the article's Creative Commons licence and your intended use is not permitted by statutory regulation or exceeds the permitted use, you will need to obtain permission directly from the copyright holder. To view a copy of this licence, visit http://creativecommons.org/licenses/by/4.0/. amounts of meltwaters and a relatively highly-inclined palaeoslope. Ablation floods are common hydrological features of the glaciomarginal zone, especially on the proximal zone of sandurs (Boothroyd and Ashley 1975; Church and Gilbert 1975; Warburton 1999; PisarskaJamroży and Börner 2011). The flow rate can be increased by various factors: firstly, a large supply of fresh ablation waters during the period of ice-sheet melting; secondly, the presence of morphological barriers caused by confined flows and a relative increase of flow competence, especially during flood events; and thirdly, the occurrence of glacial floods associated with the drainage of subglacial or proglacial reservoirs. Traces of such high- 
energy floods are recorded usually both in the morphology of sandurs and in the sedimentary records. In morphology, they can be represented by large-scale antidunes (Baker 1973; Szafraniec 2008, 2010; Carling et al. 2009; Weckwerth et al. 2019; Benito and Thorndycraft 2020), kettle holes and ice-block obstacle marks developed as results of the deposition and melting of ice blocks carried by floods (Maizels 1983; Marren and Schuh 2009; Russell 2009; Burke et al. 2010; Høgaas and Longva 2016; Weckwerth et al. 2019) or gravel bars (Høgaas and Longva 2016; Benito and Thorndycraft 2020). In the sedimentary record, they can be discovered as (1) thick, widespread sub-horizontal tabular units of massive and poorly-bedded gravels and boulders; (2) thick, coarse-grained, upwards-coarsening successions; (3) coarse-grained bedforms (bars or dunes); (4) sedimentary structures associated with obstacle marks; (5) kettle holes; or, (6) rip-up clasts (following Maizels 1997; Marren and Schuh 2009). In contrast, while such morphological and sedimentary indicators have been recorded in the proximal zones of sandurs (see Eynon and Walker 1974; Boothroyd and Ashley 1975; Boothroyd and Nummedal 1978; Fraser 1993; Zieliński 1993; Maizels 1997; Marren and Schuh 2009; Pisarska-Jamroży and Zieliński 2014; Pochocka-Szwarc and Krzyszkowski 2015; Weckwerth et al. 2019), just a few evidences of such events exist in the distal zones.

The sedimentation style of the Pleistocene sandurs deposited at the foreland of the Fennoscandian Ice Sheet, NE Poland, from the proximal to the distal zones, was described in detail by Zieliński (1993) and by Zieliński and Van Loon (2003). However, these studies examined relatively small sandurs of $50 \mathrm{~km}$ in length; these are much shorter than those in western and central Pomerania, such as the Drawa, Gwda, and/or Wda sandurs, which were measured over $100 \mathrm{~km}$ in length and called as 'Pomeranian sandurs' in this paper (i.e. sandurs deposited during the Pomeranian phase of late Weichselian). Moreover, sedimentary successions of these large sandurs have only been analysed in proximal zones (Karczewski 1989; Rachlewicz 1991; Pisarska-Jamroży and Zieliński 2014), and as mentioned above, their distal zones remain poorly understood.

It is generally accepted that the age of Pleistocene sandurs is linked to the age of end moraines determining the extent of the ice sheet margin (see Galon and Roszkówna 1961; Kozarski 1986; Lüthgens et al. 2011; Pisarska-Jamroży and Zieliński 2014). Lüthgens et al. (2011) showed that sandur deposits can prove the presence of an ice sheet position for a long time period. It should be noted, however, that in the territory of Poland, North Germany and Denmark, the Weichselian glaciation is characterized by several phases of ice sheet development, accompanied by a permanent outflow of meltwaters resulting in sandur formation. Therefore, in the sedimentary record, sandur levels have been found to correspond to the deposition phases occurring in the periods of ice sheet advance and recession (Kempton and Goldthwait 1959; Maizels 1989; Marks 1990; Olszewski and Weckwerth 1999).

The aims of this study are threefold: (1) to reconstruct the palaeoenvironmental depositional conditions of the large sandur and its palaeohydrological features; (2) to compare the sediments in the distal zone of the Gwda sandur with previously-documented distal sandurs; and, (3) to create a new temporal-spatial model of large sandurs.

\section{Geological and geomorphological setting}

The Stobno study site $\left(53^{\circ} 07^{\prime} 15^{\prime \prime} \mathrm{N}, 16^{\circ} 42^{\prime} 05^{\prime \prime} \mathrm{E}\right)$ is situated in the distal zone of the Gwda sandur (Bartczak 2006), $92 \mathrm{~km}$ south of the end moraines of the Pomeranian phase (Marine Isotope Stage 2/MIS 2), and about $5 \mathrm{~km}$ north of the northern edge of the Torun-Eberswalde Ice Marginal Valley (Fig. 1). The Gwda sandur was the subject of numerous studies in the last century focused on the processes taking place during the deglaciation of the Fennoscandian Ice Sheet (Ost 1933; Galon and Roszkówna 1961; Roszkówna 1968).

The Gwda sandur is $97 \mathrm{~km}$ in length, measured from the town of Sępolno Wielkie in the north to Ługi Ujskie in the south (Fig. 1). The inclination of the Gwda sandur depositional surface reaches approximately $0.14^{\circ}$ over a distance of $10 \mathrm{~km}$ and then only $0.08^{\circ}$ over a further 90 $\mathrm{km}$ towards the south. The sediments investigated in the Stobno study site are exposed from the present-day surface up to $7 \mathrm{~m}$ below it, while the entire sandur succession is over $17 \mathrm{~m}$ thick (see Bartczak 2006). It consists of mainly glaciofluvial sands and gravels deposited southwards from the ice margin during the Pomeranian phase of late Weichselian glaciation (MIS 2). The sandur is at least $37 \mathrm{~m}$ thick in the proximal part (Winnicki 2011; Multan and Dobosz 2012) but thins in the distal part to a little over $17 \mathrm{~m}$ near the Stobno study site (Bartczak 2006). In the most proximal zone, the Gwda sandur merges with the great sandur formed by the outflow of proglacial waters from the ice sheet front during the Pomeranian phase (Fig. 1a). This free and extensive deposition of glaciofluvial sediments was made possible by a lack of significant morphological barriers (Fig. 1a).

There are three sandur levels in the study area (Figs. 1, 2). The first (the oldest one) level (I level), lying between $105 \mathrm{~m}$ a.s.l. on the edge of the till plain and $80 \mathrm{~m}$ a.s.l. in the Piła area, is associated with the earliest stage of the ice sheet recession in this area. A second sandur level (II level) is related to the next stage of deglaciation. Its surface is inclined $0.08^{\circ}$ to the south, from $80 \mathrm{~m}$ a.s.l. in the Piła area to $71 \mathrm{~m}$ a.s.l. in the village of Stobno. This level was cut afterwards by 


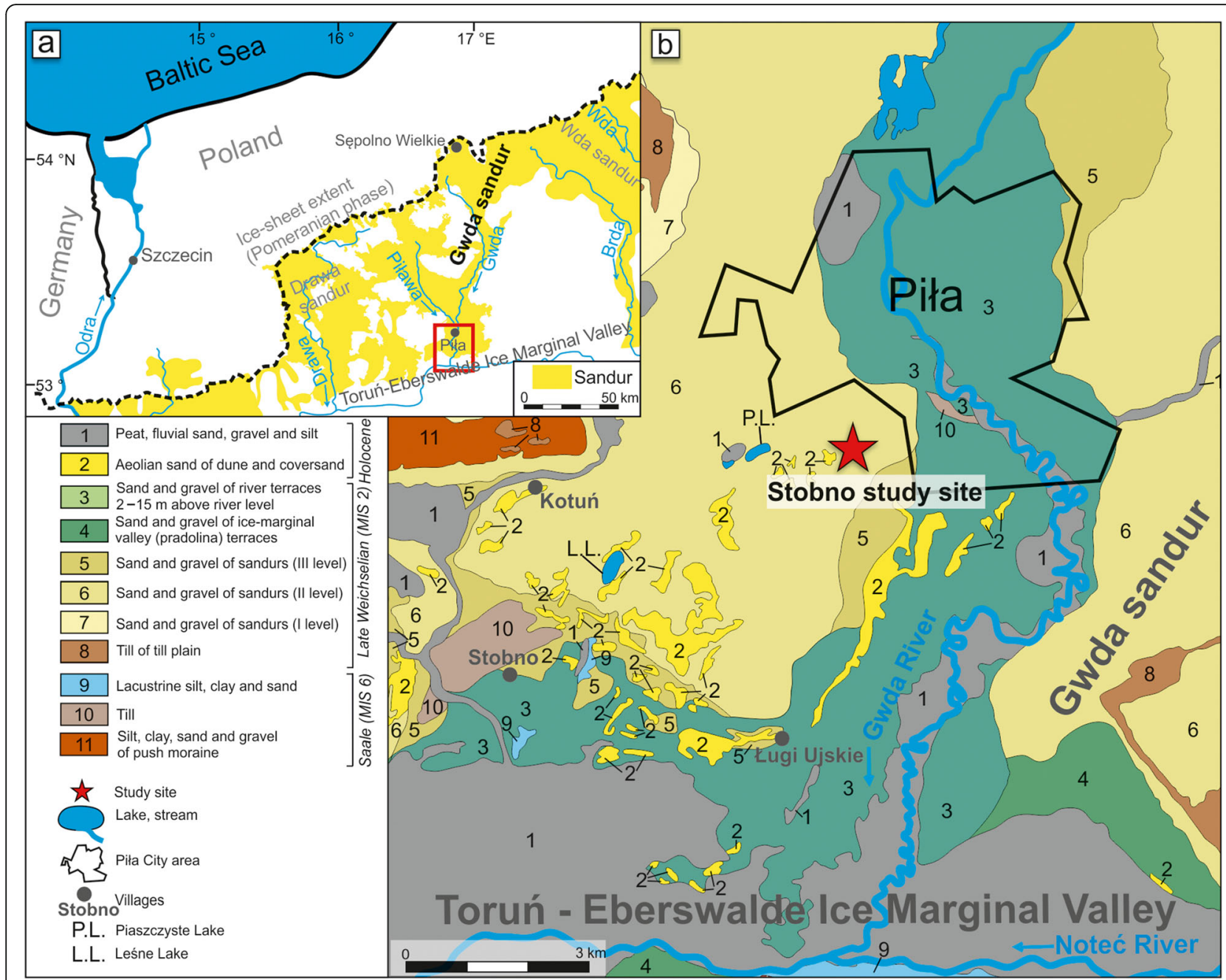

Fig. 1 The Stobno study site locality. a Distribution of sandurs south of the Pomeranian phase limit; $\mathbf{b}$ Geological setting of the study site (modified from Bartczak 2006)

successive erosional stages of the Gwda sandur formation. On the sandur surface, widespread kettle holes evolved as an effect of melting blocks of dead ice. Two such depressions, Piaszczyste Lake and Leśne Lake (Figs. 1, 2), are about $1 \mathrm{~km}$ from the study site. A third (the youngest) sandur level (III level) (71-63 $\mathrm{m}$ a.s.l.) is linked to the depositional processes in the final phase of the Pomeranian phase and with the deposition of the Gwda River.

\section{Methods}

The following sedimentological investigations were carried out in the outcrop: a description of sedimentary succession, measurement of the dip and azimuth of sediment structure, determination of maximum particle size (MPS) by measuring gravel diameter, and sampling for grain-size analyses and optically stimulated luminescence (OSL) dating.
Sediment grain size was classified according to the Udden-Wentworth scale (Udden 1914; Wentworth 1922). Sediments were coded according to Miall (1977, 1978), with modifications by Zieliński and Pisarska-Jamroży (2012) (Table 1); the term 'fines' was used to refer to clay and silt together. We use the term 'glaciofluvial' in relation to the fluvial environment in which the water derives from ice sheet. The MPS was calculated on the basis of the ten largest grains derived from gravels, sandy gravels or gravelly sands; this value is used for calculating palaeohydraulic parameters, including mean flow velocity $(v)$, bed shear stress $(\tau)$ and flow power $(\omega)$ (Table 2). Estimation of flow depth $(d)$ was based on the bar height (i.e. thickness of planar cross-stratified gravelly sands; see Table 2) or the trough depth (in trough cross-stratified sands and gravelly sands; see Table 2 ). 


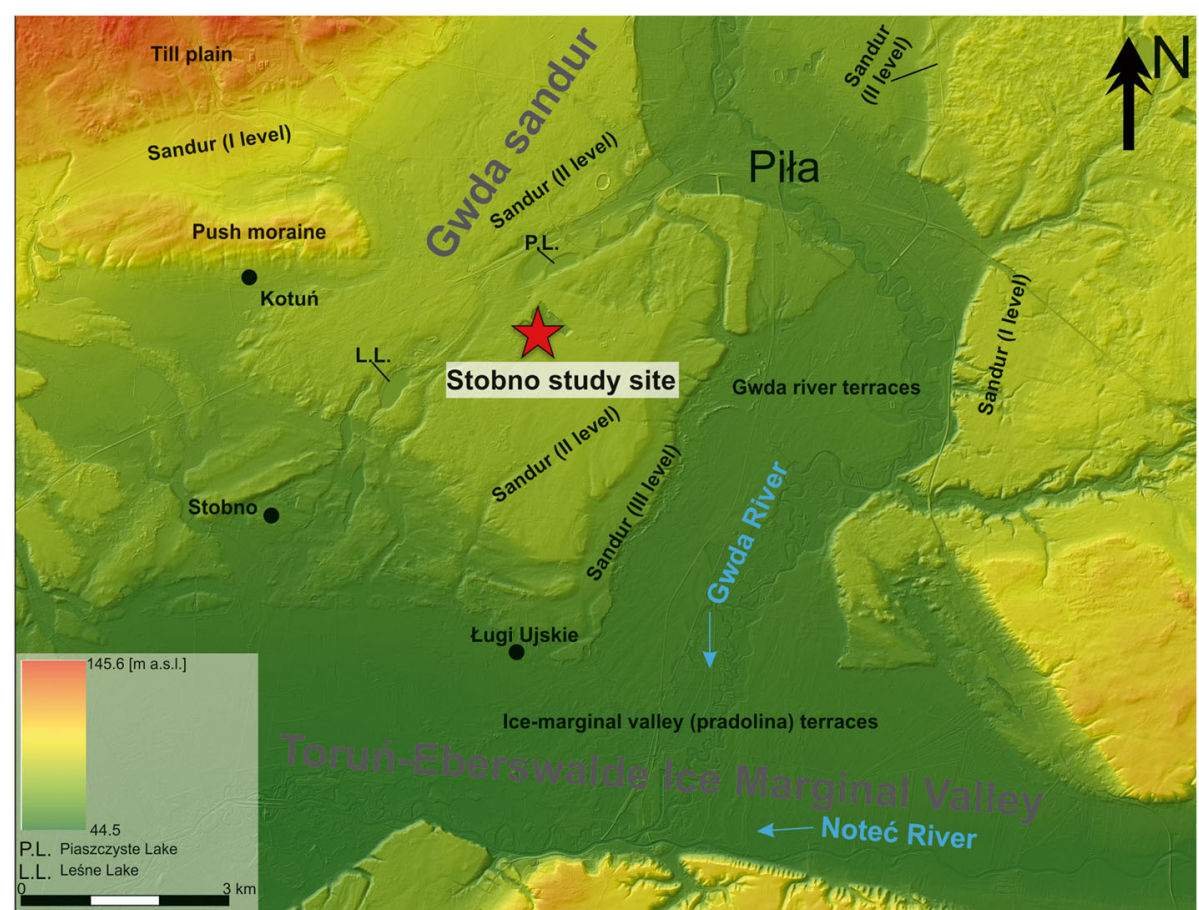

Fig. 2 Digital elevation model of the Stobno study site showing three sandur levels in the study area

Furthermore, four sandy samples were taken for OSL dating and dated at the GADAM Gliwice Luminescence Laboratory in Poland, using standard multi-grain aliquots. Equivalent doses of samples were determined using the $6 \mathrm{~mm}$ aliquot regenerative-dose (SAR) protocol (see Thrasher et al. 2009). The Central Age Model (CAM) was used to identify the central tendency in the dose distribution. The samples derived from sediments deposited in the shallow flow in a channel or in an overbank subenvironment due to their smaller flow depth and lower aggradation rate, what is the best source for OSL dating in glaciofluvial sediments (see Weckwerth et al. 2013).

Table 1 Textural and structural symbols used in the present study

\begin{tabular}{|c|c|c|}
\hline \multicolumn{3}{|c|}{ Abbreviations of sediments with their structure } \\
\hline Symbol & Grain size & Structure \\
\hline$G p$ & Gravels & \multirow{3}{*}{ Planar cross-stratification } \\
\hline GSp & Sandy gravels & \\
\hline$S G p$ & \multirow{2}{*}{ Gravelly sands- } & \\
\hline SGt & & \multirow{2}{*}{ Trough cross-stratification } \\
\hline St & \multirow{5}{*}{ Sands } & \\
\hline $\mathrm{Se}$ & & Erosional scour fill \\
\hline Sh & & Horizontal lamination \\
\hline $\mathrm{Sr}$ & & Ripple cross-lamination \\
\hline Src & & Climbing ripple cross-lamination \\
\hline FSw & Sandy fines & Wavy lamination \\
\hline$F m$ & Fines & Massive \\
\hline
\end{tabular}

Abbreviations of sediments with their structure refer to Zieliński and Pisarska-Jamroży (2012): Gp Gravels with planar cross-stratification; GSp Sandy gravels with planar cross-stratification; SGp Gravelly sands with planar cross-stratification; SGt Gravelly sands with trough cross-stratification; St Sands with trough crossstratification; Se Sands with erosional scour fill structure; Sh Sands with horizontal lamination; Sr Sands with ripple cross-lamination; Src Sands with climbing ripple cross-lamination; FSw Sandy fines with wavy lamination; Fm Massive fines 
Table 2 Palaeohydraulic formulae used in calculations in the present study (Bagnold 1966; Friend and Moody-Stuart 1972; Klimek 1972; Miller et al. 1977; Koster 1978; Saunderson and Jopling 1980; Carling 1983; Costa 1983; Williams 1983; Komar 1996; Bridge 2003; Zieliński 2014)

\begin{tabular}{|c|c|}
\hline \multicolumn{2}{|c|}{ Palaeohydraulic parameters } \\
\hline Formula & Reference \\
\hline \multicolumn{2}{|c|}{ Mean flow velocity } \\
\hline $\begin{array}{l}v=160 D^{0.45}, \mathrm{D}[\mathrm{cm}], v\left[\mathrm{~cm} \cdot \mathrm{s}^{-1}\right] \\
\mathrm{D}-\text { Mean grain size }\end{array}$ & Miller et al. (1977) \\
\hline$v=49 \mathrm{D}^{0.381}, \mathrm{D}[\mathrm{cm}], v\left[\mathrm{~cm} \cdot \mathrm{s}^{-1}\right]$ & Koster (1978) \\
\hline$v=5.9 \mathrm{D}^{0.5}, \mathrm{D}[\mathrm{m}], v\left[\mathrm{~m} \cdot \mathrm{s}^{-1}\right]$ & Costa (1983) \\
\hline 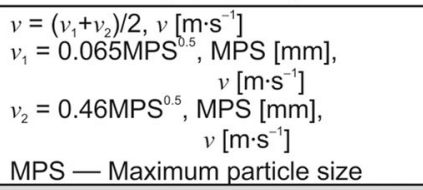 & Williams (1983) \\
\hline \multicolumn{2}{|c|}{ Bed shear stress } \\
\hline$\tau_{c r}=110 D^{0.38}, \mathrm{D}[\mathrm{cm}], \tau\left[\mathrm{dyn} \cdot \mathrm{cm}^{-2}\right]$ & Carling (1983) \\
\hline$\tau_{\mathrm{cr}}=0.16 \mathrm{D}^{1,21}, \mathrm{D}[\mathrm{mm}], \tau\left[\mathrm{N} \cdot \mathrm{m}^{-2}=\mathrm{Pa}\right]$ & Costa (1983) \\
\hline$\tau_{\mathrm{cr}}=108 \mathrm{D}^{0,57}, \mathrm{D}[\mathrm{cm}], \tau\left[\mathrm{dyn} \cdot \mathrm{cm}^{-2}\right]$ & Komar (1996) \\
\hline $\begin{aligned} & \tau=\left(\tau_{1}+\tau_{2}\right) / 2 \\
& \tau_{1}=3.9 \mathrm{MPS}, \mathrm{MPS}[\mathrm{mm}], \\
& \tau\left[\mathrm{N} \cdot \mathrm{m}^{-2}=\mathrm{Pa}\right] \\
& \tau_{2}=0.17 \mathrm{MPS}, \mathrm{MPS}[\mathrm{mm}], \\
& \tau\left[\mathrm{N} \cdot \mathrm{m}^{-2}=\mathrm{Pa}\right]\end{aligned}$ & Williams (1983) \\
\hline \multicolumn{2}{|c|}{ Flow power } \\
\hline$\omega=\tau v, \omega\left[\mathrm{W} \cdot \mathrm{m}^{-2}\right], v\left[\mathrm{~m} \cdot \mathrm{s}^{-1}\right], \tau[\mathrm{Pa}]$ & Bagnold (1966) \\
\hline \multicolumn{2}{|c|}{ Bedform height } \\
\hline $\begin{array}{l}\mathrm{h}_{\mathrm{mr}}=3 \mathrm{~h}_{\mathrm{t}}[\mathrm{m}] \\
\mathrm{h}_{\mathrm{mr}}-3-D \text { dunes height } \\
\mathrm{h}_{\mathrm{t}}-\text { Thickness of lithofacies (St, SG }\end{array}$ & Bridge (2003) \\
\hline $\begin{array}{l}h_{b}=1.25 h_{p}[\mathrm{~m}] \\
h_{b}-\text { Bar height } \\
h_{p}-\text { Thickness of lithofacies (SGp, }\end{array}$ & $\begin{array}{l}\text { Saunderson and Jopling (1980) } \\
\text { Sp) }\end{array}$ \\
\hline \multicolumn{2}{|c|}{ Flow depth } \\
\hline $2 \leq d / h_{m r} \leq 5$ & Zieliński (2014) \\
\hline$d \cong \mathrm{h}_{b}$ & $\begin{array}{l}\text { Friend and Moody-Stuart (1972) } \\
\text { Klimek (1972) }\end{array}$ \\
\hline
\end{tabular}

$\boldsymbol{v}$ Mean flow velocity; $\boldsymbol{\tau}$ Bed shear stress; $\boldsymbol{\omega}$ Flow power; $\boldsymbol{d}$ Flow depth; $\boldsymbol{s}$ Second; $\boldsymbol{N}$ Newton; $\boldsymbol{P a}$ Pascal

\section{Results}

The geomorphological position in relation to the entire Gwda sandur clearly indicates that the sediments in the Stobno study site are part of the distal zone. The sediments in the study site reached up to $7.5 \mathrm{~m}$ in thickness, and the sediments extended up to $200 \mathrm{~m}$ along a north-south direction (Figs. 3, 4a). Within these sediments, three sedimentary units, were recognized: (1) lower unit - fine-grained sands with ripple cross-lamination and horizontal lamination; (2) middle unit - gravelly coarse-grained sands and sandy gravels with planar cross-stratification; and, (3) upper unit - sands and gravelly sands with trough crossstratification (Fig. 3).

\subsection{The lower sedimentary unit: horizontally-laminated sands and ripple cross-laminated sand $(\mathrm{Sh}, \mathrm{Sr})$ 4.1.1 Description}

The lower sedimentary unit has a thickness of at least 4 $\mathrm{m}$; however, its bottom part was not exposed (Figs. 3, 4a). The upper boundary of this sedimentary unit has erosional features. It consists of sands with ripple crosslamination $(S r)$ and horizontal lamination $(S h)$ as well as secondary (less common) sediments: massive fines $(F m)$, climbing ripple cross-laminated sands $(\mathrm{Src})$ and wavylaminated sandy fines $(F S w)$, in order of occurrence (Fig. 4b). The thickness of the beds varies from $10 \mathrm{~cm}$ (massive fines) to $80 \mathrm{~cm}$ (horizontal laminated sands). The boundaries between beds are depositional features. 


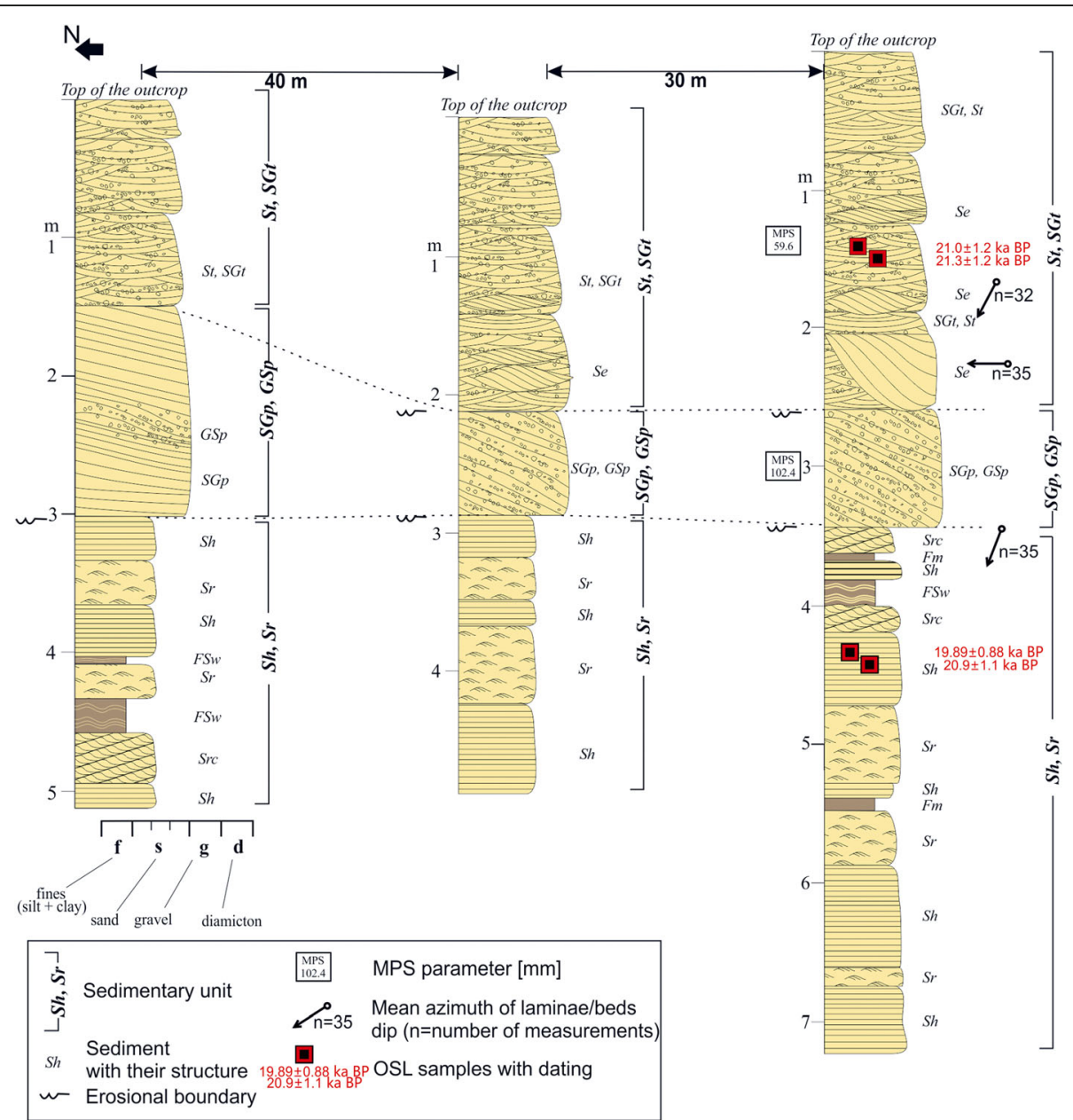

Fig. 3 Sedimentary logs in the Stobno study site. For explanation see Table 1

The gradation in the sediments is normal: from medium- and coarse-grained sands to fine-grained sands at the top. The laminae of the climbing ripple crosslaminated sands dip to the southwest. Two types of rhythms are observed within this unit: horizontal laminated sands $\rightarrow$ ripple cross-laminated sands $(S h \rightarrow S r)$, which occurs four times, and ripple cross-laminated sands $\rightarrow$ horizontal laminated sands $(\mathrm{Sr} \rightarrow \mathrm{Sh})$, occurring twice.

\subsubsection{Interpretation}

The lower sedimentary unit is a record of a low-energy braided river environment with three-dimensional sandy ripples deposited under the conditions of the lower part of the flow regime, i.e., in low-power zones. The ripple cross-laminated sands were deposited from weak and shallow currents (type 12 according to Miall 1985). The migration of linguoid or lunate ripples appeared to be synchronous with the filling of troughs eroded in flow separation zones. It is likely that these bedforms were initially long and small, typical for the upper part of the lower-flow regime, but were later replaced by higher ripples representing the lower-energy conditions. In addition, ripple cross-laminated sands were likely deposited in an overbank position or in an abandoned channel. Similar sandy rippled forms were described from overbank deposits in braided-river environments (Tanner and Hubert 1992; Bridge and Lunt 2006). Similarly, sands with horizontal lamination were formed by settling from the suspension in quiet water in an abandoned channel or an overbank basin (cf. Miall 1985; Zieliński 1993). The two identified rhythms indicate gradual changes in flow depth associated with changes in bed configuration: from a flat sandy bottom to ripples $(S h \rightarrow S r)$ and from ripples to a sandy bottom $(S r \rightarrow S h)$. The lack of erosional boundaries between sediments suggests that these changes did not occur rapidly but rather gradually. The presence of intercalations of massive and wavy-laminated fines indicates that the deposition took place in episodes of waning current. Similar finegrained sediments were known from fluvial cycles linked to sheetfloods in braided channel environments (Blakey 

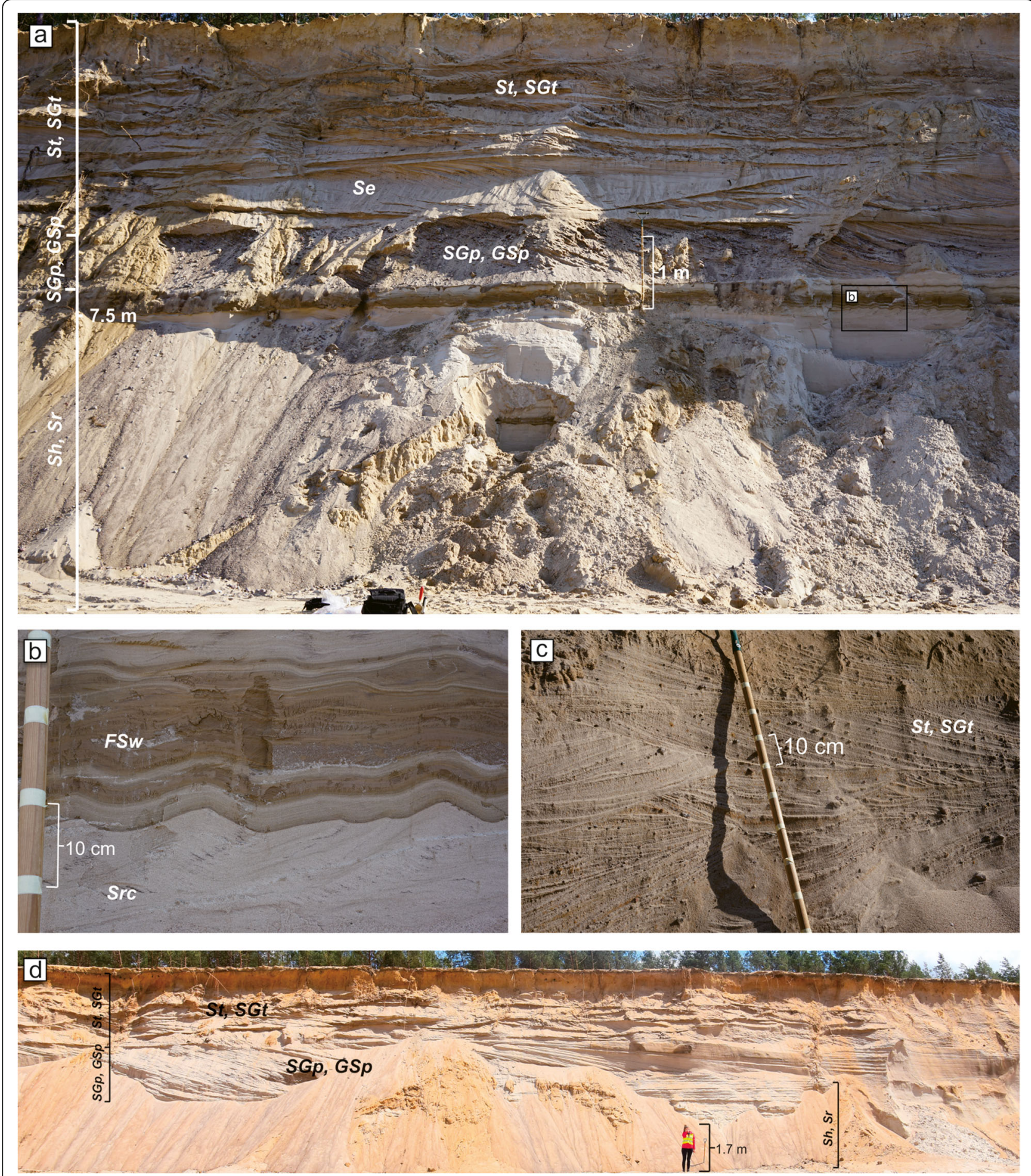

Fig. 4 Sedimentary details of glaciofluvial succession in the Stobno study site. a Stobno study site succession with marked three sedimentary units; b Wavy-laminated sandy fines (FSW) and climbing ripple cross-laminated sands (Src) of low-energy parts of braided river system; c Trough cross-stratified sands $(S t)$ and gravelly sands $(S G t)$ of the uppermost part indicate megaripples in the deepest parts of the braided river channels; d Sediments deposited by high-energy flows in braided channels 
and Gubitosa 1984; Kjær et al. 2004). It is possible that a previously-active braided river channel became a pool with a stagnant water due to avulsion. The palaeocurrent direction, measured from ripplecross lamination, indicates that the sediment was transported from the northeast to the southwest (Fig. 3).

\subsection{The middle sedimentary unit: planar cross-stratified sandy gravels and gravelly sands (GSp, SGp) \\ 4.2.1 Description}

The middle sedimentary unit is comprised of planar cross-stratified gravelly sands $(S G p)$ and sandy gravels (GSp), gradually ranging in thickness from $0.5 \mathrm{~m}$ in the south to $2 \mathrm{~m}$ in the north (Fig. $4 \mathrm{a}, \mathrm{d}$ ). The lateral extent of this unit reaches $70 \mathrm{~m}$. Both the bottom and top boundaries of these beds have erosive features. The matrix-supported deposits of this unit contain an admixture of fine- and medium-sized gravels. The MPS measured from this unit can reach $10.2 \mathrm{~cm}$.

\subsubsection{Interpretation}

The middle sedimentary unit of the Stobno study site succession records the migration of the straight-crested (2-D) dunes of gravelly sands and sandy gravels, indicating the presence of a current in the middle part of the lower flow regime in a braided river channel (Harms 1969; Bridge 2003). This form type is characteristic of braided channels with much bedloads (cf. Thorne et al. 1993). In addition, the presence of large gravelly bars is the record of initial waning phases of powerful floods (Blodgett and Stanley 1980). The palaeohydraulic parameters were estimated as: mean flow velocity $(v)=\sim 2.6$ $\mathrm{m} \cdot \mathrm{s}^{-1}$; bed shear stress $(\tau)=\sim 32.9 \mathrm{~Pa}$; flow power $(\omega)=$ $85.5 \mathrm{~N} \cdot \mathrm{m}^{-1} \cdot \mathrm{s}^{-1}$; and, the maximum flow depth $(d)$ reached $2.5 \mathrm{~m}$ (Table 3 ).

\subsection{The upper sedimentary unit: trough cross-stratified} sands and gravelly sands (St, SGt)

\subsubsection{Description}

The upper sedimentary unit consists of a sets of trough cross-stratified sands $(S t)$ and gravelly sands (SGt) (Fig. 4c). The thickness of this unit is up to $2.5 \mathrm{~m}$, while the thickness of an individual bed reaches $0.4 \mathrm{~m}$. The $S t$, SGt beds of this upper unit dip to the southwest (Fig. 3). Both sands and gravely sands with trough cross-stratification demonstrate an abundance of a fine- and medium-sized gravel admixture. Gravelly sands with trough cross-stratification are also characterised by a matrix-supported texture. The MPS measured from this unit is $5.9 \mathrm{~cm}$. Within this upper sedimentary unit of the study succession, large-scale erosional scour fills $(\mathrm{Se})$ can be seen in the southern part of the outcrop (Figs. 3, 4a). These erosional scour fills are wide (up to $10 \mathrm{~m}$ ) and relatively shallow (up to $0.8 \mathrm{~m}$ ); the beds are arranged sigmoidal (Fig. 4a) and dip to the west (Fig. 3).

\subsubsection{Interpretation}

The upper sedimentary unit represents the migration of 3 -D dunes, reflecting the nature of the water current in the upper part of the lower flow regime (cf. Harms 1969; Bridge 2003). Deposition of dunes occurs under conditions of relatively deep and rapid flow in braided river channels, deposited during the diminishing discharge after a large flood (cf. Middleton and Trujillo 1984; Zieliński 1993). The trough cross-stratified sands reflect a channel bed in an advanced phase of the diminishing discharge. In conditions of decreased flow competency, the gravelly sand dunes would be replaced by sandy three-dimensional dunes classified as compound dunes by Harbor (1998). The palaeocurrent direction indicates that the sediments were transported from the northeast to the southwest (Fig. 3). The flow depth $(d)$ obtained from the single troughs is between $2.4 \mathrm{~m}$ and $6 \mathrm{~m}$, while the mean flow velocity $(v)$ is about $2 \mathrm{~m} \cdot \mathrm{s}^{-1}$, the bed shear stress $(\tau)$ is about $21.5 \mathrm{~Pa}$, and the flow power $(\omega)$ is $43 \mathrm{~N} \cdot \mathrm{m}^{-1} \cdot \mathrm{s}^{-1}$ (Table 3). In the erosional scour fill,

Table 3 Comparison of the palaeohydraulic parameters estimated from the sediments in Stobno study site with those of previous studies

\begin{tabular}{|c|c|c|c|c|c|}
\hline Source of sediments with references & Sediments & $\begin{array}{c}\text { Flow depth } \\
{[\mathrm{m}]}\end{array}$ & $\begin{array}{c}\text { Mean velocity } \\
{\left[\mathrm{m} \cdot \mathrm{s}^{-1}\right]}\end{array}$ & $\begin{array}{l}\text { Bed shear } \\
\text { stress [Pa] }\end{array}$ & $\begin{array}{c}\text { Flow power } \\
{\left[\mathrm{N} \cdot \mathrm{m}^{-1} \cdot \mathrm{s}^{-1}\right]}\end{array}$ \\
\hline \multirow{2}{*}{ Stobno study site } & $S G p$ & 2.5 & $\sim 2.6(1.2-4.6)$ & $\sim 32.9(20.8-43.3)$ & 85.5 \\
\hline & St/SGt & $2.4-6$ & $\sim 2(1.0-3.6)$ & $\sim 21.5(12.1-29.9)$ & 43 \\
\hline \multirow{2}{*}{ Proximal zone of sandurs (Zieliński 1993) } & $G p$ & $3-4$ & $1-5$ & $75-250$ & $100-300$ \\
\hline & St/SGt & $1-3$ & $1.9-2.7$ & $24-46$ & $45-125$ \\
\hline \multirow{2}{*}{ Distal zone of sandurs (Zieliński 1993) } & $S G p$ & $0.8-1$ & $0.8-2.1$ & $12-23$ & $10-46$ \\
\hline & St/SGt & $0.8-2.3$ & $1.6-2.1$ & $24-36$ & $40-68$ \\
\hline \multirow{2}{*}{ Ice-marginal valley (Pisarska-Jamroży 2015) } & $S G p$ & $0.4-3.1$ & $1-1.8$ & $28.5-91.6$ & $28-161.3$ \\
\hline & St/SGt & $2.1-8.4$ & $1-2.3$ & $28.5-152.6$ & $28-347$ \\
\hline
\end{tabular}




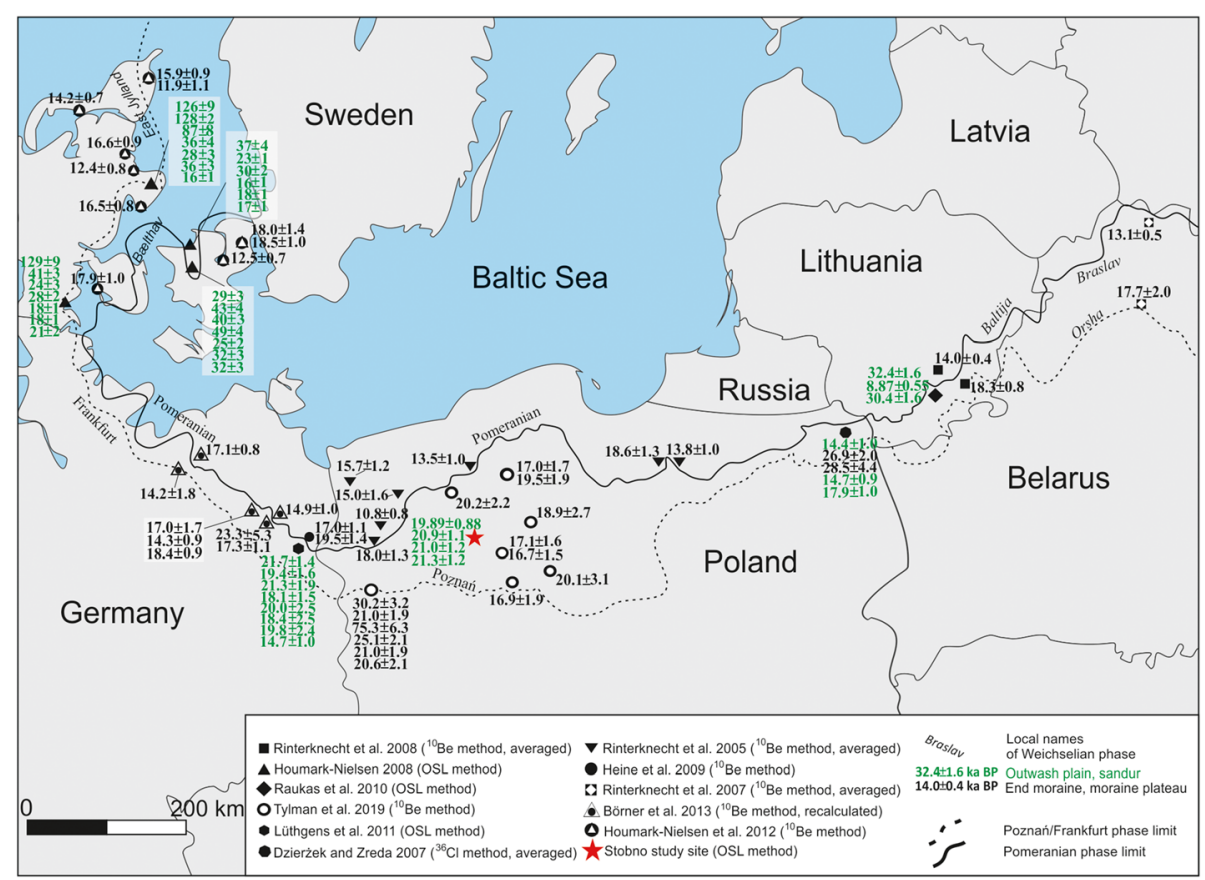

Fig. 5 Dating results of the Pomeranian and Poznań phases of the late Weichselian glaciation (Marine Isotope Stage 2/MIS 2) in the Baltic Sea coast area. Locations and dating results based on: Rinterknecht et al. (2005, 2007, 2008, 2014); Dzierżek and Zreda (2007); Houmark-Nielsen (2008); Heine et al. (2009); Raukas et al. (2010); Lüthgens et al. (2011); Houmark-Nielsen et al. (2012); Tylman et al. (2019). ka BP=Thousand years before the present

large trough structures, observed only in the southern part of the outcrop (Fig. 4a), represent the erosional forms dissected in the confluence zones of two channels, which were so-called scour pools (Siegenthaler and Huggenberger 1993; Pisarska-Jamroży et al. 2010; Zieliński 2014). The palaeocurrent direction measured from these large-scale erosional scour fills show sediment transport took place from the east to the west. This sedimentary unit was formed under conditions where erosion, transport and deposition were in balance with the current energy (equilibrium flow).

\section{Synthesis and discussion}

This section will be divided into four parts: first, to discuss the sedimentological features of the studied sediments; subsequently to discuss their calculated palaeohydraulic parameters; the third, to show OSL dating discrepancies of the studied sediments; and, finally to point out the palaeogeographical implications for a new temporal and spatial model of the long-term sandur deposition.

\subsection{Sedimentological features of the studied sediments}

The trough infills, found in the Stobno study site, developed in the deep and rapid flow of braided river channels, were most likely deposited during a period of diminishing discharge following a large flood. The initial waning phase of the flood, characterised by significant bedload transport and rapid variations in velocity, depth, power and discharge by currents, also resulted in the deposition of straight-created dunes. The confluence zones of the channels developed erosional scour pools, a typical feature of a braided river system (cf. PisarskaJamroży et al. 2010). Sandy and gravelly straight-crested (2-D) dunes were deposited in braided river channels with much bedload. The fine-grained sandy sediments were deposited from stagnant water or in weak current conditions in an overbank position or in an abandoned channel. The mean palaeocurrent direction shows that the sediments in Stobno study site were transported from the northeast to the southwest; however, the palaeocurrent direction can vary considerably on the local scale, e.g. in the confluence zones of braided channels, and in this case, it indicates the transport from the east to the west.

The sandy and gravelly trough infills observed in the sediments of the Stobno study site are typical for the proximal zones of sandurs (see Zieliński 1993; PisarskaJamroży 2006, 2008a, 2008b), but not for the distal zones, which are characterised by sandy and finer sediments (Zieliński 1993). The distal zone typically comprises sandy deposits, reflecting the deposition of alluvial sediments by relatively shallow and low-energy braided channels (Zieliński 1993), which were expected in the Stobno study site. 


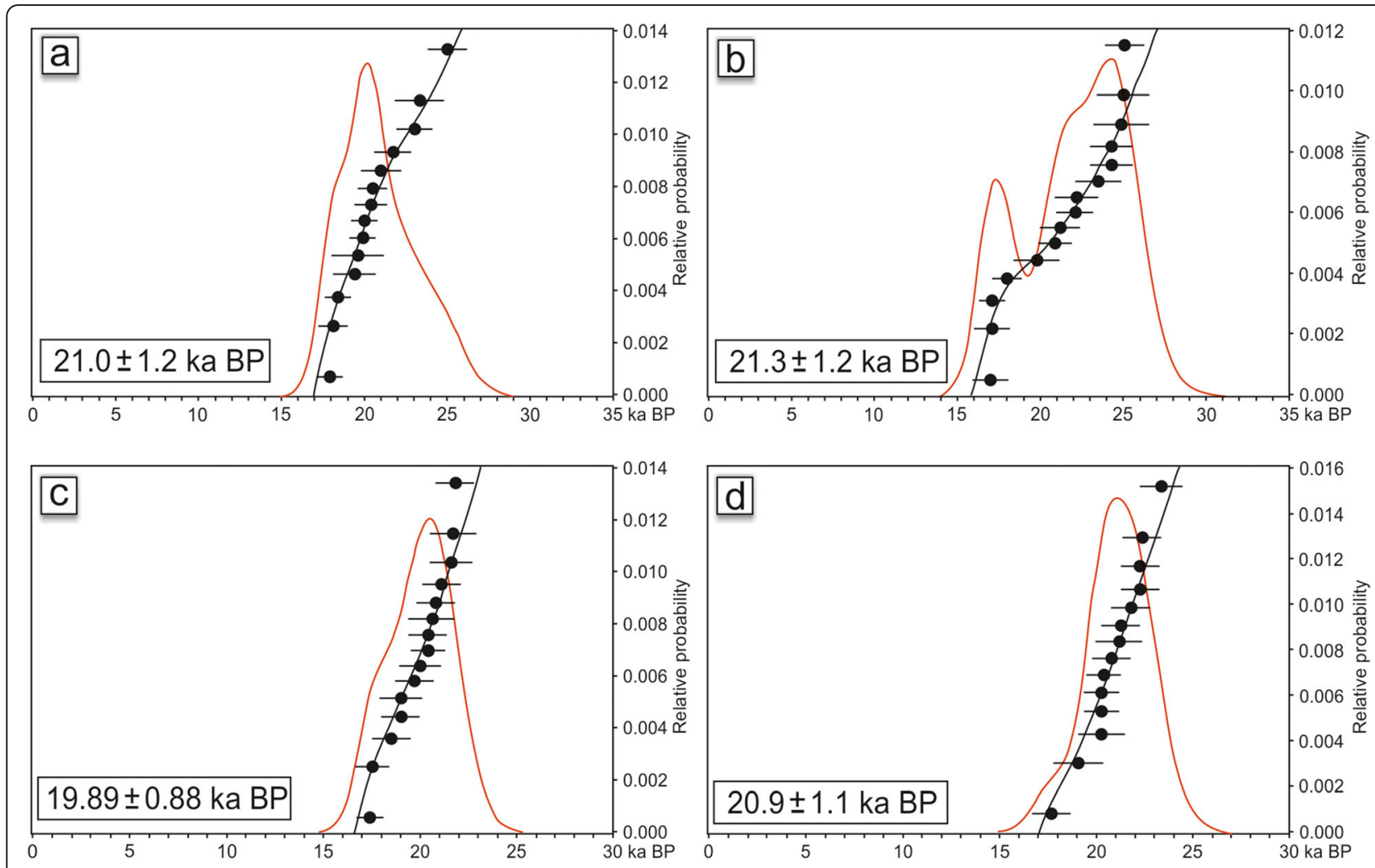

Fig. 6 Distribution of luminescence measurements calculated on the Central Age Model (CAM) based from $1 \mathrm{mg}$ of pure quartz grains. $\mathbf{a}-\mathbf{b}$ The OSL ages obtained from the upper sedimentary unit $(S t, \mathbf{S G t})$; $\mathbf{c}-\mathbf{d}$ The OSL ages obtained from the lower sedimentary unit (Sh)

\subsection{Palaeohydraulic parameters calculated for the studied sediments}

The maximum bed shear stress of the channels in the Stobno study site reaches a maximum value of $32.9 \mathrm{~Pa}$. Although this value is larger than those previously calculated for the sandy and gravelly braided channels of the middle zone of sandurs $(3<\tau<20 \mathrm{~Pa})$ (Boothroyd and Ashley 1975), and calculated for flows observed during low-water levels in proximal sandurs $(\tau<15 \mathrm{~Pa})$ (Ashworth and Ferguson 1986), it is smaller than those estimated for catastrophic flows related to glacial floods, such as $\sim 90 \mathrm{~Pa}$ (Lord and Kehew 1987; Komar 1989), $75<\tau<250 \mathrm{~Pa}$ (Zieliński 1993), or $120<\tau<400 \mathrm{~Pa}$ (Zieliński 2014). The bed shear stress calculated in the Stobno study site is comparable with those calculated by Zieliński (1993) for the proximal zone of sandurs and by Pisarska-Jamroży (2015) for catastrophic flows in the Toruń-Eberswalde Ice Marginal Valley $(28.5<\tau<152.6$ $\mathrm{Pa}$ ). The flow power in the analysed part of the Gwda sandur varies from $\sim 43 \mathrm{~N} \cdot \mathrm{m}^{-1} \cdot \mathrm{s}^{-1}$ for troughs with gravelly sands to $\sim 85.5 \mathrm{~N} \cdot \mathrm{m}^{-1} \cdot \mathrm{s}^{-1}$ for gravelly sands of the transverse bar (Table 3). These values are comparable with those calculated for the proximal zone of sandurs by Zieliński (1993). The palaeohydraulic parameters estimated for the sediments in the Stobno study site are relatively different with the expected parameters for the distal zone of a sandur (cf. Zieliński and Van Loon 2003). The channel form and the bedform height suggest that the flow depth in the Stobno study site reaches up to $6 \mathrm{~m}$ in the deepest part of the channels (Table 3). Similar results were obtained for the channel bars in the proximal zone of sandurs (see Zieliński 1993; Table 3) or for the Torun-Eberswalde Ice Marginal Valley, which collected waters from all Pomeranian sandurs (PisarskaJamroży 2015). The mean flow velocity in the Stobno study site ranges from $2 \mathrm{~m} \cdot \mathrm{s}^{-1}$ to $2.6 \mathrm{~m} \cdot \mathrm{s}^{-1}$ (Table 3), which is also more typical for the proximal than the distal zones of sandurs (see Zieliński 1993).

Summing up, we interpret that the palaeohydraulic parameters like flow depth, mean flow velocity, bed shear stress, and flow power obtained from the studied sediments tend to proximal depositional conditions than distal depositional conditions.

\subsection{Dating discrepancies of the studied sediment}

The range of dating methods are used for sediments which do not fit comparable time scales, for example, OSL dating determines the time of the last exposure of sands and silts to (sun) light (see Wallinga 2002; Murray and Olley 2002), while ${ }^{10}$ Be dating determines the time 


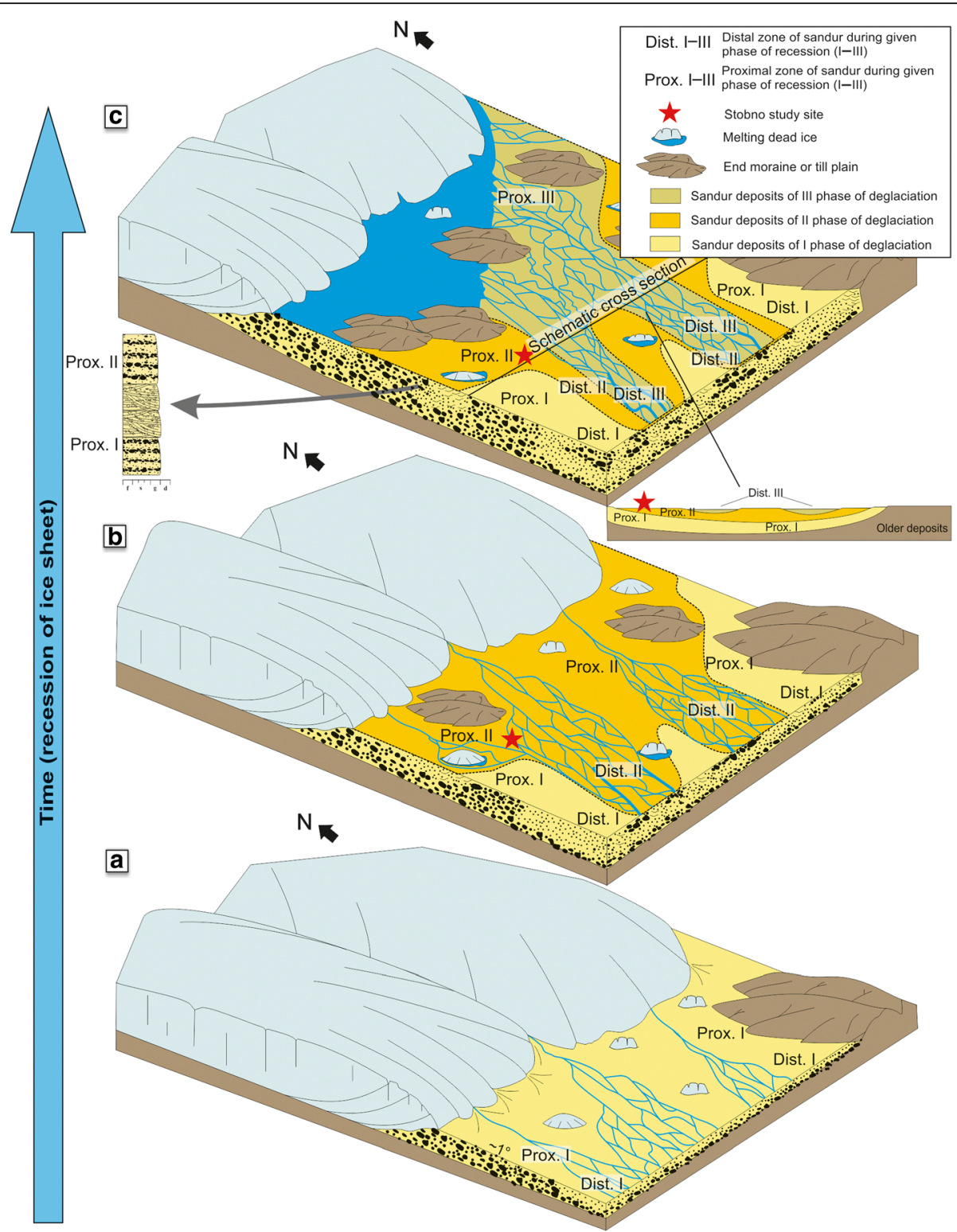

Fig. 7 Schematic model of the late Weichselian ice sheet recession phases and sandur development with marked proximal parts of the sandur moving northwards: a First phase of recession; $\mathbf{b}$ Second phase of recession; c Third phase of recession

of the surface exposure (see Rinterknecht et al. 2012). The problem occurs when the same dating method is used but the dating result demonstrates a wide range of ages.

${ }^{10}$ Be dating of the erratic boulders and OSL dating of the Pomeranian phase sediments indicate that they were formed in between $14.8 \mathrm{ka}$ BP and $15.8 \mathrm{ka}$ BP in Poland (Rinterknecht et al. 2005), and in between $14.2 \mathrm{ka} \mathrm{BP}$ and $21.7 \mathrm{ka}$ BP further west, in Germany (Lüthgens et al. 2011; Börner et al. 2013) (Fig. 5). This age variation could be attributed to a number of causes, such as the sediment redeposition, the bank erosion, and/or the limitation of solar resetting (see Adrielsson and
Alexanderson 2005; Raukas and Stankowski 2005; Alexanderson et al. 2008; Weckwerth et al. 2013; Dzieduszyńska et al. 2014). Alexanderson and Murray (2012) proposed that the accuracy of OSL dating is influenced by various factors including the transport distance, the sediment reworking, and origin of grains from sedimentary rocks, which are positively correlated with a better bleached signal. Lüthgens et al. (2011) suggested that the multiple reworkings of grains before the final deposition enhanced the bleaching probability.

The distribution of dose equivalent for the four OSL ages from the Stobno study site mainly show monomodal graphs (Fig. 6). All obtained OSL ages (19.89 \pm 0.88 
ka BP, $20.9 \pm 1.1 \mathrm{ka} \mathrm{BP}, 21.0 \pm 1.2 \mathrm{ka} \mathrm{BP}$ and $21.3 \pm 1.2 \mathrm{ka}$ BP; Fig. 6) demonstrate good bleaching, i.e., their uncertainties are between $5 \%$ and $6 \%$, which are all in the range $(5 \%-10 \%)$ of the OSL-age uncertainty proposed by Duller (2008) or are better. The OSL ages of the sediments in the Stobno study site are at least four thousand years older than the age of the Pomeranian phase in Poland, i.e. 14.3-17 ka BP (see Rinterknecht et al. 2005; Marks 2012), but are in the range of OSL ages obtained for the Pomeranian phase in Germany, i.e. 15.6-21.7 ka BP (Lüthgens et al. 2011; Börner et al. 2013).

In the light of our present contribution, we can expect that large sandurs like the Gwda sandur were deposited over a longer period than previously thought, and the OSL dating discrepancies of sediments deposited in the distal and proximal zones of the Gwda sandur indicate a timespan in the range of a few thousand years for the deposition.

\subsection{Palaeogeographical implications}

How can the coexistence of the apparently incoherent data given above be reconciled? We assume that the distal position of the Stobno study site within the Gwda sandur indicated by its general geomorphological position and altitude model, and the obtained OSL ages of the studied sediments and their sedimentological and palaeohydrological interpretation, are all correct. Then the glaciofluvial sediments of the Gwda sandur appeared to have been deposited over a few thousand years. As the ice sheet path migrated northward, so did the proximal zone of the Gwda sandur, up to the position of the present-day Pomeranian phase indicated by end moraines (Fig. 7). During this period, the palaeosurfaces of the Gwda sandur were modified, washed out and eroded many times by proglacial currents which occasionally displayed the features of catastrophic floods (see: results in Section 5.3). Moreover, during the recession of the ice sheet between phases, the meltwaters caused the erosion and subsequent infilling of large troughs in the proximal zone of the sandur, which are now in the distal zone (Fig. 7a). The modification of the sandur palaeosurfaces, as well as the deposition, happened during the recession and stagnation of the ice sheet front (Fig. 7b, c). The most likely explanation for the appearance of coarsegrained sediments in the present-day distal zone of the sandur is spatial change in the position of the proximal zone of the sandur, which is linked to the position of the ice sheet front (Fig. 7).

\section{Conclusions}

The following conclusions can be drawn from this study:

1) Large sandurs, such as the Gwda sandur, demonstrate more complicated internal architecture than was previously thought, and the division of sandurs into proximal and distal zones according to their sedimentological features is an oversimplification.

2) The sedimentary features in the distal part of sandurs indicate that the deposition was highly energetic.

3) The palaeohydraulic parameters (flow depth, mean flow velocity, and/or bed shear stress) estimated based on the distal sediments are comparable with those obtained for the proximal zones of other sandurs.

4) The proximal zone of large sandurs can be shifted over time according to the migration of an ice sheet front.

\section{Acknowledgements}

Both authors are grateful to the National Science Centre Poland for the financial support by Grant No. 2017/25/N/ST10/00322. We thank the reviewers and editors for their constructive comments to improve the manuscript.

\section{Authors' contributions}

M. Mleczak carried out the fieldwork, prepared sections 1-6 and all figures M. Pisarska-Jamroży prepared the abstract and sections 4-6. The interpretation of the obtained research results and conclusions were carried out by both authors. All authors read and approved the final manuscript.

\section{Funding}

The study is financially supported by the National Science Centre Poland (Grant No. 2017/25/N/ST10/00322).

\section{Availability of data and materials}

All data generated or analyzed in the current study are available from the corresponding author on reasonable request.

\section{Declaration}

\section{Competing interests}

The authors declare that they have no known competing financial interests or personal relationships that could have appeared to influence the work reported in this paper.

Received: 7 October 2020 Accepted: 12 March 2021

Published online: 19 May 2021

\section{References}

Adrielsson, L., and H. Alexanderson. 2005. Interactions between the Greenland ice sheet and the Liverpool land coastal ice cap during the last two glaciation cycles. Journal of Quaternary Science 20 (3): 269-283. https://doi.org/10.1002/jqs.900.

Alexanderson, H., K.O. Eskola, and K.F. Helmens. 2008. Optical dating of a late Quaternary sediment sequence from Skoli, northern Finland. Geochronometria 32: 51-59.

Alexanderson, H., and A.S. Murray. 2012. Problems and potential of OSL dating Weichselian and Holocene sediments in Sweden. Quaternary Science Reviews 44: 37-50. https://doi.org/10.1016/j.quascirev.2009.09.02

Ashworth, P.J., and R.I. Ferguson. 1986. Interrelationships of channel processes, changes and sediments in a proglacial braided river. Geografiska Annaler 68 (4): 361-371. https://doi.org/10.1080/04353676.1 986.11880186

Bagnold, R.A. 1966. An approach to the sediment transport problem from general physics. US Geological Survey Professional Paper 422: 1-37. 
Baker, V.R. 1973. Palaeohydrology and sedimentology of Lake Missoula flooding in eastern Washington. Geological Society of America Special Papers 144: 1-79. https://doi.org/10.1130/SPE144-p1.

Bartczak, E. 2006. Explanations to the detailed geological map of Poland, scale 1:50000, Sheet Piła, 50. Warszawa: Polish Geological Institute (in Polish).

Benito, G., and V.R. Thorndycraft. 2020. Catastrophic glacial-lake outburst flooding of the Patagonian ice sheet. Earth-Science Reviews 200: 102996. https://doi.org/10.1016/j.earscirev.2019.102996.

Blakey, R.C., and R. Gubitosa. 1984. Controls of sandstone body geometry and architecture in the Chinle formation (upper Triassic), Colorado plateau. Sedimentary Geology 38 (1-4): 51-86. https://doi.org/10.1016/0037-0738(84 190074-5.

Blodgett, R.H., and K.O. Stanley. 1980. Stratification, bedforms, and discharge relations of the Platte braided river system, Nebraska. Journal of Sedimentary Petrology 50: 139-148.

Boothroyd, J.C., and G.M. Ashley. 1975. Processes, bar morphology and sedimentary structures on braided outwash fans, North-eastern Gulf of Alaska. In: Jopling, A.V., and B.C. McDonald. (Eds.). Glaciofluvial and Glaciolacustrine Sedimentation. Tulsa, Oklahoma, USA: Society of Economic Paleontologists and Mineralogists Special Publication, 23: pp. 193-222. https://doi.org/10.2110/pec.75.23.0193.

Boothroyd, J.C., and D. Nummedal. 1978. Proglacial braided outwash: a model for humid alluvial-fan deposits. In: Miall, A.D. (Ed.). Fluvial Sedimentology. Calgary, Alberta, Canada: Canadian Society of Petroleum Geologists, Memoir 5: pp. 641-668

Börner, A., V. Rinterknecht, D. Bourlès, and R. Braucher. 2013. Erste Ergebnisse von Oberflächenexpositionsdatierungen an glazialen Großgeschieben durch in-situ gebildetes kosmogenes Beryllium-10 in Mecklenburg-Vorpommern (Nordostdeutschland). Zeitschrift für Geologische Wissenschaften 41 (3): 123-143.

Bridge, J.S. 2003. Rivers and floodplains. Forms, processes, and sedimentary record, 491. Oxford, United Kingdom: Blackwell.

Bridge, J.S., and I.A. Lunt. 2006. Depositional models of braided rivers. In: Sambrook-Smith, G.H., J.L. Best, C.S. Bristow, and G.E. Petts. (Eds.). Braided Rivers: Process, Deposits, Ecology and Management. Oxford, United Kingdom: Blackwell. International Association of Sedimentologists Special Publication 36: pp. 11-50. https://doi.org/10.1002/9781444304374.ch2.

Burke, M.J., J. Woodward, A.J. Russell, P.J. Fleisher, and P.K. Bailey. 2010. The sedimentary architecture of outburst flood eskers: A comparison of ground-penetrating radar data from Bering glacier, Alaska and Skeidararjökull, Iceland. Geological Society of America Bulletin 122 (9-10): 1637-1645. https://doi.org/10.1130/B30008.1

Carling, P.A. 1983. Threshold of coarse sediment transport in broad and narrow natural streams. Earth Surface Processes and Landforms 8 (1): 1 18. https://doi.org/10.1002/esp.3290080102.

Carling, P.A., I.P. Martini, J. Herget, P. Borodavko, and S. Parnachov. 2009. Megaflood sedimentary valley fill: Altai Mountains, Siberia. In: Burr, D.M., P.A. Carling, and V. R. Baker. (Eds.). Megaflooding on Earth and Mars. Cambridge University Press, Cambridge: pp. 243-264. https:/doi.org/10.1017/CBO9780511635632.013.

Church, M., and R. Gilbert. 1975. Proglacial fluvial and lacustrine sediments. In: Jopling, A.V., and B. McDonald. (Eds.). Glaciofluvial and Glaciolacustrine Sedimentation. Tulsa: Society of Economic Paleontologists and Mineralogists, Special Publication 23: pp. 22-100. https://doi.org/10.2110/pec.75.23.0022.

Costa, J.E. 1983. Paleohydraulic reconstruction of flash-flood peaks from boulder deposits in the Colorado front range. Geological Society of America Bulletin 94 (8): 986-1004. https://doi.org/10.1130/0016-7606(1 983)94<986:PROFPF>2.0.CO;2.

Duller, G.A.T. 2008. Single-grain optical dating of quaternary sediments: Why aliquot size matters in luminescence dating. Boreas 37 (4): 589-612. https://doi.org/10.1111/j.1502-3885.2008.00051.x.

Dzieduszyńska, D., J. Petera-Zganiacz, J. Twardy, P. Kittel, P. Moska, and G. Adamiec. 2014. Optical dating and sedimentary record from the terrace depositional profile of the Warta river (Central Poland). Geochronometria 41 (4): 361-368. https://doi.org/10.2478/s13386-013-0173-y.

Dzierżek, J., and M. Zreda. 2007. Timing and style of deglaciation of northeastern Poland from cosmogenic ${ }^{36} \mathrm{Cl}$ dating of glacial and glaciofluvial deposits. Geological Quarterly 51: 203-216.
Eynon, G., and R.G. Walker. 1974. Facies relationships in Pleistocene outwash gravels, southern Ontario: A model for bar growth in braided rivers. Sedimentology 21 (1): 43-70. https://doi.org/10.1111/j.1365-3091.1974. tb01781.x.

Fraser, G.S. 1993. Sedimentation in an interlobate outwash stream. Sedimentary Geology 83 (1-2): 53-70. https://doi.org/10.1016/0037-073 8(93) $90182-5$.

Friend, P.F., and M. Moody-Stuart. 1972. Sedimentation of the Wood Bay formation (Devonian) of Spitsbergen: Regional analysis of a late orogenic basin. Norsk Polarintitut Skifter 157: 1-77.

Galon, R., and L. Roszkówna. 1961. Extents of the Scandinavian glaciations and of their recession stages on the territory of Poland in the light of analysis of the marginal forms of inland ice. Przeglad Geograficzny 33: 347-364.

Harbor, D.J. 1998. Dynamics of bedforms in the lower Mississippi River. Journal of Sedimentary Research 68 (5): 750-762. https://doi.org/10.2110/ jsr.68.750.

Harms, J.C. 1969. Hydraulic significance of some sand ripples. Geological Society of America Bulletin 80 (3): 363-396. https://doi.org/10.1130/00167606(1969)80[363:HSOSSR]2.0.CO;2.

Heine, K., A.U. Reuther, H.U. Thieke, R. Schulz, N. Schlaak, and P.W. Kubik. 2009. Timing of Weichselian ice marginal positions in Brandenburg (northeastern Germany) using cosmogenic in situ ${ }^{10}$ Be. Zeitschrift für Geomorphologie 53 (4): 433-454. https://doi.org/10.1127/0372-8854/2 009/0053-0433.

Høgaas, F., and O. Longva. 2016. Mega deposits and erosive features related to the glacial lake Nedre Glomsjø outburst flood, southeastern Norway. Quaternary Science Reviews 151: 273-291. https://doi.org/10.1016/j.qua scirev.2016.09.015.

Houmark-Nielsen, M. 2008. Testing OSL failures against a regional Weichselian glaciation chronology from southern Scandinavia. Boreas 37 (4): 660-677. https://doi.org/10.1111/j.1502-3885.2008.00053.x.

Houmark-Nielsen, M., H. Linge, D. Fabel, C. Schnabel, S. Xu, K.M. Wilcken, and S. Binnie. 2012. Cosmogenic surface exposure dating the last deglaciation in Denmark: Discrepancies with independent age constraints suggest delayed periglacial landform stabilisation Quaternary Geochronology 13: 1-17. https://doi.org/10.1016/j.quageo.2 012.08.006.

Karczewski, A. 1989. Morfogeneza strefy marginalnej fazy pomorskiej na obszarze lobu Parsęty w vistulianie (Pomorze Środkowe), AMU Press, Geography Series 44, 48 (in Polish with English summary).

Kempton, J.P., and R.P. Goldthwait. 1959. Glacial outwash terraces of the hocking and Scioto river valleys, Ohio. The Ohio Journal of Science 59: 135-151.

Kjær, K.H., L. Sultan, J. Krüger, and A. Schomacker. 2004. Architecture and sedimentation of outwash fans in front of the Myrdalsjökull ice cap, Iceland. Sedimentary Geology 172 (1-2): 139-163. https://doi.org/10.1016/ j.sedgeo.2004.08.002.

Klimek, K. 1972. Present-day fluvial processes and relief of the Skeidararsandur plain (Iceland). Prace Geograficzne, Polska Akademia Nauk 94: 1-139 (in Polish with English summary).

Komar, P.D. 1989. Flow competence evaluations of the hydraulic parameters of floods: an assessment of the technique. In: Beven, K., and P.A. Carling. (Eds.). Floods: Hydrological, Sedimentological and Geomorphological Implications. Wiley, Chichester: pp. 107-134.

Komar, P.D., 1996. Entrainment of sediments from deposits of mixed grain sizes and densities. In: Carling, P.A., and M.R. Dawson. (Eds.). Advances in Fluvial Dynamics and Stratigraphy. Wiley, Chichester: pp. 127-181.

Koster, E.H. 1978. Transverse ribs: their characteristics, origin, and paleohydrologic significance. In: Miall, A.D. (Ed.). Fluvial Sedimentology. Calgary, Alberta, Canada: Canadian Society of Petroleum Geologists, Memoirs 5: pp. 161-186.

Kozarski, S. 1986. Time scales and the rhythm of Vistulian geomorphic events in the Polish Lowland. Czasopismo Geograficzne 57: 247-270.

Lord, M.L., and A.E. Kehew. 1987. Sedimentology and palaeohydrology of glacial lake outburst deposits in SE Saskatchewan and NW North Dakota. Geological Society of America Bulletin 99 (5): 663-673. https://doi. org/10.1130/0016-7606(1987)99<663:SAPOGO>2.0.CO;2. 
Lüthgens, C., M. Böse, and F. Preusser. 2011. Age of the Pomeranian icemarginal position in northeastern Germany determined by Opically Stimulated Luminescence (OSL) dating of glaciofluvial sediments. Boreas 40 (4): 598-615. https://doi.org/10.1111/j.1502-3885.2011.00211.x.

Maizels, J.K. 1983. Palaeovelocity and palaeodischarge determination for coarse gravel deposits. In: Gregory, K.J. (Ed.). Background to Paleohydrology. Wiley, Chichester: pp. 101-139.

Maizels, J.K. 1989. Differentiation of late Pleistocene terrace outwash deposits using geomorphic criteria: Tekapo valley, South Island, New Zealand. New Zealand Journal of Geology and Geophysics 32 (2): 225241. https://doi.org/10.1080/00288306.1989.10427585.

Maizels, J.K. 1997. Jökulhlaup deposits in proglacial areas. Quaternary Science Reviews 16 (7): 793-819. https://doi.org/10.1016/S0277-3791(97)00023-1.

Marks, L. 1990. Outline of geology and evolution of the Northwestern Kurpie outwash, Northern Poland. Geological Quarterly 34: 489-502 (in Polish with English summary).

Marks, L. 2012. Timing of the late Vistulian (Weichselian) glacial phases in Poland. Quaternary Science Reviews 44: 81-88. https://doi.org/10.1016/j. quascirev.2010.08.008

Marren, P.M., and M. Schuh. 2009. Criteria for identifying jökulhlaup deposits in the sedimentary record. In: Burr, D.M., P.A. Carling, and V.R. Baker (Eds.). Megaflooding on Earth and Mars. Cambridge University Press, New York: pp. 225-242. https://doi.org/10.1017/CBO9780511635632.012.

Miall, A.D. 1977. A review of the braided-river depositional environment. Earth-Science Reviews 13 (1): 1-62. https://doi.org/10.1016/0012-8252 (77) $90055-1$.

Miall, A.D. 1978. Lithofacies types and vertical profile models in braided rivers: a summary. In: Miall, A.D. (Ed.). Fluvial Sedimentology. Calgary, Alberta, Canada: Canadian Society of Petroleum Geologists, Memoirs 5: pp. 597-604.

Miall, A.D. 1985. Architectural-element analysis: A new method of facies analysis applied to fluvial deposits. Earth-Science Reviews 22 (4): 261-308. https://doi.org/10.1016/0012-8252(85)90001-7.

Middleton, L.T., and A.P. Trujillo. 1984. Sedimentology and depositional setting of the U. Proterozoic Scanlan Conglomerate, central Arizona. In: Koster, E.H., and R.J. Steel. (Eds.). Sedimentology of Gravels and Conglomerates. Calgary, Alberta, Canada: Canadian Society of Petroleum Geologists, Memoirs, pp. 189-201.

Miller, G.H., J.T. Andrews, and S.K. Short. 1977. The last interglacial/glacial cycle, Clyde Foreland, Baffin Island, N.W.T.: Stratigraphy, biostratigraphy and chronology. Canadian Journal of Earth Science 14: 2829-2857.

Multan, M., and T. Dobosz. 2012. Explanations to the detailed geological map of Poland, scale 1:50000, Sheet Koczała, 37. Warszawa: Polish Geological Institute (in Polish).

Murray, A.S., and J.M. Olley. 2002. Precision and accuracy in the optically stimulated luminescence dating of sedimentary quartz: A status review. Geochronometria 21: 1-16.

Olszewski, A., and P. Weckwerth. 1999. The deformational structures of the deposits on the Höfdabrekkujökull forefield, Mýrdalsjökull, Iceland. Landform Analysis 2: 63-80.

Ost, H.-G. 1933. Morphologische Studien im Drage- und Küddowgebiet. Abhandlungen und Berichte der naturwissenschaftlichen Abteilung der Grenzmärkischen Gesellschaft zur Erforschung und Pflege der Heimat, Band 7, 68. Schneidemühl: Friedrich-Wilhelm-Universität Berlin (in German).

Pisarska-Jamroży, M. 2006. Transition deposits between the end moraine and outwash plain in the Pomeranian glaciomarginal zone of NW Poland: A missing component of ice-contact sedimentary models. Boreas 35 (1): 126-141. https://doi.org/10.1080/03009480500359038.

Pisarska-Jamroży, M. 2008a. Zonation of glaciomarginal environment inferred from Pleistocene deposits of Mysliborz Lakeland, NW Poland. Geografiska Annaler 90A: 237-249.

Pisarska-Jamroży, M. 2008b. Depositional mechanisms in glaciomarginal zone of the Vistulian glaciation. Sedimentological study of Western Pomerania and Jutland, 163. Bydgoszcz: UKW Press (in Polish with English summary).

Pisarska-Jamroży, M. 2015. Factors controlling sedimentation in the ToruńEberswalde ice-marginal valley during the Pomeranian phase of Weichselian glaciation: An overview. Geologos 21 (1): 1-29. https://doi. org/10.1515/logos-2015-0001.
Pisarska-Jamroży, M., and A. Börner. 2011. Is the Charlottenthal fan (marginal zone of the Pomeranian phase, NE Germany) an end moraine? Geologos 17: $17-28$.

Pisarska-Jamroży, M., K. Machowiak, and D. Krzyszkowski. 2010 Sedimentation style of Pleistocene kame from the Western Sudety Mountains, S Poland. Geologos 16 (2): 101-110. https://doi.org/10.2478/ v10118-009-0008-8.

Pisarska-Jamroży, M., and T. Zieliński. 2014. Pleistocene sandur rhythms, cycles and megacycles: Interpretation of depositional scenarios and palaeoenvironmental conditions. Boreas 43 (2): 330-348. https://doi. org/10.1111/bor.12041.

Pochocka-Szwarc, K., and D. Krzyszkowski. 2015. The outwash plain of Rospuda River valley - A record of depositional environments. Studia Quaternaria 32 (2): 63-78. https://doi.org/10.1515/squa-2015-0006.

Rachlewicz, G. 1991. Morfogeneza stożka sandrowego w strefie marginalnej fazy pomorskiej koło Kołtek w świetle badań osadów przypowierzchniowych. Badania Fizjograficzne nad Polskq Zachodniq 42A: 205-228 (in Polish).

Raukas, A., and W. Stankowski. 2005. Influence of sedimentological composition on OSL dating of glaciofluvial deposits: Examples from Estonia. Geological Quarterly 49: 463-470.

Raukas, A., W. Stankowski, V. Zelčs, and P. Šinkunas. 2010. Chronology of the last deglaciation in the southeastern Baltic region on the basis of recent OSL dates. Geochronometria 36: 47-54. https://doi.org/10.2478/v10003010-0011-7.

Rinterknecht, V., A. Börner, D. Bourles, and R. Braucher. 2014. Cosmogenic ${ }^{10}$ Be dating of ice sheet marginal belts in Mecklenburg-Vorpommern, Western Pomerania (Northeast Germany). Quaternary Geochronology 19: 42-51. https://doi.org/10.1016/j.quageo.2013.05.003.

Rinterknecht, V., R. Braucher, M. Böse, D. Bourles, and J.-L. Mercier. 2012. Late Quaternary ice sheet extents in northeastern Germany inferred from surface exposure dating. Quaternary Science Reviews 44: 89-95. https:// doi.org/10.1016/j.quascirev.2010.07.026.

Rinterknecht, V.R., A. Bitinas, P.U. Clark, G.M. Raisbeck, F. Yiou, and E.J. Brook. 2008. Timing of the last deglaciation in Lithuania. Boreas 37 (3): 426433. https://doi.org/10.1111/j.1502-3885.2008.00027.x.

Rinterknecht, V.R., L. Marks, J.A. Piotrowski, G.M. Raisbeck, F. Yiou, E.J. Brook, and P.U. Clark. 2005. Cosmogenic ${ }^{10} \mathrm{Be}$ ages on the Pomeranian Moraine, Poland. Boreas 34 (2): 186-191. https://doi.org/10.1080/030094 80510012926.

Rinterknecht, V.R., I. Pavlovskaya, P.U. Clark, G.M. Raisbeck, F. Yiou, and E.J. Brook. 2007. Timing of the last deglaciation in Belarus. Boreas 36 (3): 307-313. https://doi.org/10.1111/j.1502-3885.2007.tb01252.x.

Roszkówna, L. 1968. Recesja ostatniego lądolodu z terenu Polski [Recession of the last ice sheet in Poland]. Prace Geograficzne Insytutu. Geografii PAN 74: 65-95 (in Polish).

Russell, A.J. 2009. Jökulhlaup (ice-dammed lake outburst flood) impact within a valley-confined sandur subject to backwater conditions, Kangerlussuaq, West Greenland. Sedimentary Geology 215 (1-4): 33-49. https://doi.org/10.1016/j.sedgeo.2008.06.011.

Saunderson, H.C., and A.V. Jopling. 1980. Paleohydraulics of a tabular, crossstratified sand in the Brampton esker, Ontario. Sedimentary Geology 25 (3): 169-188. https://doi.org/10.1016/0037-0738(80)90039-1.

Siegenthaler, C., and P. Huggenberger. 1993. Pleistocene Rhine gravel: deposits of a braided river system with dominant pool preservation. In: Best, J.L., and C.S. Bristow. (Eds.). Braided Rivers. London, Bath: The Geological Society. Geological Society of London Special Publication 75: pp. 147-162. https://doi.org/10.1144/GSL.SP.1993.075.01.09.

Szafraniec, J. 2008. Powodzie lodowcowe na Pomorzu - zapis w morfometrii powierzchni sandrowych. Landform Analysis 8: 73-77 (in Polish).

Szafraniec, J. 2010. Zastosowanie wskaźnika urzeźbienia powierzchni sandrowych jako informacji o charakterze drenażu lądolodu Wisły na Pomorzu. Landform Analysis 13: 117-128 (in Polish).

Tanner, L.H., and J.F. Hubert. 1992. Depositional facies, palaeogeography and palaeoclimatology of the L. Jurassic McCoy Brook Fm., Fundy Rift Basin, Nova Scotia. Palaeogeography, Palaeoclimatology, Palaeoecology 96 (3-4): 261-280. https://doi.org/10.1016/0031-0182(92)90105-E. 
Thorne, C.R., A.P.G. Russell, and M.K. Alam. 1993. Planform pattern and channel evolution of the Brahmaputra River, Bangladesh. In: Best, J.L., and C.S. Bristow. (Eds.). Braided Rivers. London, Bath: The Geological Society. Geological Society of London Special Publication 75: pp. 257276. https://doi.org/10.1144/GSL.SP.1993.075.01.01.

Thrasher, I.M., B. Mauz, R.C. Chiverrell, and A. Lang. 2009. Luminescence dating of glaciofluvial deposits: A review. Earth-Science Reviews 97 (1-4): 133-146. https://doi.org/10.1016/j.earscirev.2009.09.001.

Tylman, K., V.R. Rinterknecht, P.P. Woźniak, D. Bourles, I. Schimmelpfennig, V. Guilou, and A. Team. 2019. The local last glacial maximum of the southern Scandinavian ice sheet front: Cosmogenic nuclide dating of erratics in northern Poland. Quaternary Science Reviews 219: 36-46. https://doi.org/10.1016/j.quascirev.2019.07.004.

Udden, J.A. 1914. Mechanical composition of clastic sediments. Geological Society of America Bulletin 25 (1): 655-744. https://doi.org/10.1130/GSA B-25-655.

Wallinga, J. 2002. Optically stimulated luminescence dating of fluvial deposits: A review. Boreas 31 (4): 303-322. https://doi.org/10.1080/03 0094802320942536.

Warburton, J. 1999. Environmental change and sediment yield from glacierised basins: the role of fluvial processes and sediment storage. In: Brown, A.G., and T.A. Quine. (Eds.). Fluvial Processes and Environmental Change. Wiley, Chichester: pp. 363-384.

Weckwerth, P., K.R. Przegiętka, A. Chruścińska, and M. Pisarska-Jamroży. 2013. The relations between optical bleaching and sedimentological features of fluvial deposits in the Torun Basin (Poland). Geological Quarterly 57: $31-44$

Weckwerth, P., W. Wysota, J.A. Piotrowski, A. Adamczyk, A. Krawiec, and M. Dąbrowski. 2019. Late Weichselian glacier outburst floods in NorthEastern Poland: Landform evidence and palaeohydraulic significance. Earth-Science Reviews 194: 216-233. https://doi.org/10.1016/j.earscirev.2 019.05.006.

Wentworth, C.K. 1922. A scale of grade and class terms for clastic sediments. The Journal of Geology 30 (5): 377-392. https://doi.org/10.1086/622910.

Williams, G.P. 1983. Paleohydrological methods and some examples from Swedish fluvial environments, I - Cobble and boulder deposits. Geografiska Annaler 65A: 227-243.

Winnicki, J. 2011. Explanations to the detailed geological map of Poland, scale 1:50000, Sheet Biały Bór, 36. Warszawa: Polish Geological Institute (in Polish).

Zieliński, T. 1993. Outwash Plains of NE Poland - sediments and depositional processes. Prace Naukowe Uniwersytetu Ślaskiego 1398: 95 (in Polish with English summary).

Zieliński, T. 2014. Sedimentology. Deposits of rivers and lakes, 594. Poznań: AMU Press (in Polish).

Zieliński, T., and A.J. Van Loon. 2003. Pleistocene sandur deposits represent braidplains, not alluvial fans. Boreas 32 (4): 590-612. https://doi.org/10.1 080/03009480310004170.

Zieliński, T., and M. Pisarska-Jamroży. 2012. Which features of deposits should be included in a code and which not? Przeglad Geologiczny 60: 387-397 (in Polish with English summary).

\section{Publisher's Note}

Springer Nature remains neutral with regard to jurisdictional claims in published maps and institutional affiliations.

\section{Submit your manuscript to a SpringerOpen ${ }^{\circ}$ journal and benefit from:}

- Convenient online submission

- Rigorous peer review

- Open access: articles freely available online

- High visibility within the field

- Retaining the copyright to your article

Submit your next manuscript at $\boldsymbol{\nabla}$ springeropen.com 